\title{
Production Potentiality of Freshwater Prawn in Palair Reservoir
}

\author{
T. Suguna* \\ Fisheries Research Station, S.V. Veterinary University, \\ West Godavari, Andhra Pradesh, India \\ *Corresponding author
}

\section{A B S T R A C T}

K e y w o r d s
Palair Reservoir,
Production,
Potentiality,
Freshwater prawn,
Growth
performance, Catch,
Composition,
Morphotypes
Article Info
Accepted:
26 September 2020
Available Online:
10 October 2020

\section{Introduction}

Reservoirs are often referred to as "sleeping giants of Indian Fisheries. Reservoir or manmade lakes, are created primarily for irrigation, power generation and other water resource development process. These water bodies have become the prime inland fisheries resource of India due to many reasons: development of reservoir fisheries also brings with it many economic and social advantages, they form an important source for increasing fish and prawn production. Along with irrigation, the reservoir fisheries play a significant role in providing the livelihood opportunities to many rural fishers. Although India has vast freshwater resources, they are not fully exploited except in a limited scale for carp culture.

These are the main opportunities for improving the livelihood and nutritional security through aquaculture. Five reservoirs are located in the district Khammam, Telangana, out of which three are larger and the rest two are smaller. Kinnerasani reservoir 
is a crocodile sanctuary. Wyra and Palair reservoirs serve for Irrigation and Aqua production.

Freshwater prawn culture and fish culture technology have become popular for use in large number of tanks and ponds. However, most reservoirs are underutilized for this purpose in the country.

India is the second largest contributor of freshwater prawns to the world market. All farmed freshwater prawns today belong to the genus Macrobrachium. Until 2000 the only species farmed was the giant river prawn (scampi), Macrobrachium rosenbergii. India farms a small amount of monsoon river prawn Macrobrachium malcolmsonii. Freshwater prawn culture has attracted more attention in recent years due to its export potential and increasing demand as luxury protein.

Palair reservoir, a tributory of river Krishna, is a breath taking, beautiful reservoir located in village of Palair Kusmanchi mandal of Khammam district of Telangana. It is about $30 \mathrm{~km}$ away from district head quarters of Khammam, $2 \mathrm{~km}$ from Palair village and is on Suryapet - Khammam road. It is the balancing reservoir of Nagarjuna Sagar left canal, with water spreading over an area of 1748 ha and with a storage capacity of 2.5 TMC of water. The water here is free of pollution and offers a best place for water based adventure and entertainment. For peace seekers, this place offers a best spot to relax with its serene backdrop and an adventurous boating facility, this place provides good water sports and activities.

Apart from feeding the ayacut under the Nagarjunasgar left canal system, this reservoir is the main drinking water source for nearby villages. It is also water storage facility for a large number of villages and towns nearby Khammam.
The water from this reservoir is diverted to nearly 17 canals, which includes Bonakal branch canal and Mangapuram branch canal for irrigation.

This reservoir is also serving as a sole source of livelihood for over 14,500 members enrolled in as many as 184 fishermen cooperative societies in district.

Palair reservoir is $28-30 \mathrm{~km}$ from head quarter of Khammam. The purpose of this reservoir is irrigation, aquaculture activity, employment and electricity generation. Locationally it is $17^{\circ}-12^{\prime}-12^{\prime} \mathrm{N}$ latitude and $79^{\circ}-54^{\prime}-10^{\prime} \mathrm{E}$ longitude. Ijhhght's water basin is river Krishna with a maximum water level of +444.310 mts. and Maximum dam highest of 20.57 mts. The full Reservoir level is +439.310 meters with catchment area of 651.24 sq.mts. The average rainfall is 790 $\mathrm{mm}$.

The Palair reservoir is a balancing reservoir and is a major hub of freshwater fish and prawn culture. Its abundant water resources, earn a niche for itself in freshwater fish and prawn production, in the entire region. The freshwater fish and prawn are "must-eat" here as good quality / fresh variety of them are readily available. The freshness of the lake water makes it a good place for rearing fish and prawn thus enhancing the economical growth.

According to sources, the production of freshwater fish and prawn production is estimated to be over 16,000 MT and 500 MT respectively.

The freshwater prawn culture now occupies a significant position in inland aquaculture practices. The practice of culturing prawn in ponds / tanks and reservoir is floushring because farming in these water bodies is proving to be a better practice compared to 
capture fisheries in lakes, rivers, canals or streams or estuaries in India. These offer immense potential for fresh water prawn culture and there is a possibility to increase the prawn production from reservoirs.

Keeping in view of this aqua potential in reservoir and the lucarative market prices has attracted to study the catch composition and production potentiality of Palair reservoir which provides ready information for further ranching of seed in reservoir, which will upgrade the socio-economic standards of fishermen community of the area.

\section{Description of Palair Reservoir}

\begin{tabular}{|c|l|c|l|}
\hline 1. & Village & - & Palair \\
\hline 2. & Mandal & - & Kusmanchi \\
\hline 3. & $\begin{array}{l}\text { Distance from } \\
\text { km }\end{array}$ & - & $23 \mathrm{~km}$ \\
\hline 4. & $\begin{array}{l}\text { Purpose of } \\
\text { reservoir }\end{array}$ & - & $\begin{array}{l}\text { Irrigation, } \\
\text { culture, electricity, } \\
\text { generative }\end{array}$ \\
\hline 5. & Latitudes & - & $17^{\circ}-12^{\prime}-12^{\prime} \mathrm{N}$ \\
\hline 6. & Longitudes & - & $79^{\circ}-54^{\prime}-10^{\prime} \mathrm{E}$ \\
\hline 7. & Water basin & - & Krishna \\
\hline 8. & $\begin{array}{l}\text { Full reservoir } \\
\text { level }\end{array}$ & $+439.310 \mathrm{mts}$ \\
\hline 9. & $\begin{array}{l}\text { Maximum } \\
\text { water level }\end{array}$ & $+444.310 \mathrm{mts}$ \\
\hline 10. & $\begin{array}{l}\text { Maximum } \\
\text { height of Dam }\end{array}$ & $20.57 \mathrm{mts}$. \\
\hline 11. & Catchment area & 651.24 sq.mts \\
\hline 12. & $\begin{array}{l}\text { Average rain } \\
\text { fall }\end{array}$ & $790 \mathrm{~mm}$. \\
\hline & & & \\
\hline
\end{tabular}

\section{Materials and Methods}

Culture trails of freshwater prawn have been carried out successfully in Palair reservoir of Khammam district. Fishermen of the concerned reservoirs regularly stock wild freshwater prawn juveniles from the Godavari River in Andhra Pradesh every year in the months of July to August. The prawns grow until February after which they start harvesting the prawn until June. Study carried out from August 2018 - April 2019.

Monthly samplings were done regularly to identify the species in the catch composition and morphotypes.

The hydrobiological, physico chemical parameters are recorded fortnightly.

The growth performance of the obtained species were recorded fortnightly.

The seasonal variance of qualitative and quantitative analysis of plankton are assessed.

\section{Results and Discussion}

The members of fisherman cooperative societies of both Khammam and Nalgonda districts, embark on fishing in Palair Reservoir. They initiate their fishing activity usually in the month of April / May as per the permission of officials, state department of fisheries (1a, 1b, 1c, 1d, 1e).

The average yield obtained was recorded as 300 tonnes of fish and 70 tonnes of prawns. The catch composition of fresh water prawn (Fig. 2), growth (parameters) performance (Fig. 6), seasonal qualitative and quantitative variance of plankton (Fig. 7), water quality parameters (Table 1) and various morphotypes in freshwater prawn (Fig. 3,4,5,) and quality production potentiality of Palair Reservoir, Telangana (Fig. 8) are recorded as below.

In catch composition the percentage of $M$. malcolmsonii is found to be $80 \%$ whereas $M$. rosebergii is $20 \%$ (Fig. 1e, 2,3,4). The morphotypes like runt, orange clawed and blue clawed in males and in female immature, mature, gravid, spent are observed in $M$. rosenbergii (Fig. 4). The monthly growth performance of freshwater prawn is very 
encouraging with a mean weight of $60 \mathrm{gm}$ (Fig. 6). The blue green algae, green algae and diatoms are noticed under phytoplankton whereas protozoa, rotifers, copepods and cladocerans are observed under zooplankton. Quantitatively phytoplankton are high in rainy season whereas zooplankton in winter season (Fig. 7). Significantly a progressive Freshwater prawn production potentiality of Palair Reservoir is recorded (Fig. 8). During the study all the water quality parameters are noticed to be in favourable range (Table 1).

Table.1 Range of water quality parameters in Palair reservoir

\begin{tabular}{|c|c|c|c|c|c|c|}
\hline $\begin{array}{c}\text { Month of } \\
\text { samplings }\end{array}$ & \multicolumn{2}{|c|}{ Temperature } & pH & D.O. (mg / & Depth (It) & $\begin{array}{c}\text { Alkalinity } \\
\text { (mg/lt) }\end{array}$ \\
\hline July - May & 27.50 & Water & & & & \\
\hline
\end{tabular}

Fig.1

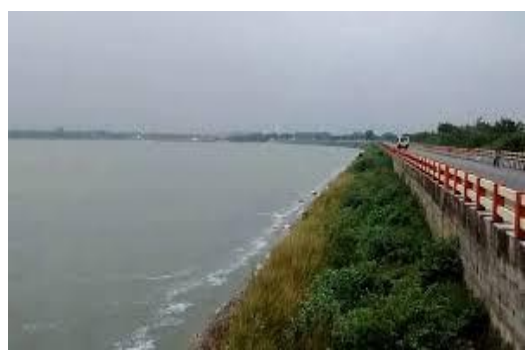

1a Palair reservoir

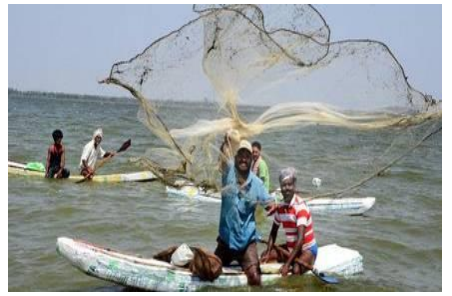

1c Harvesting

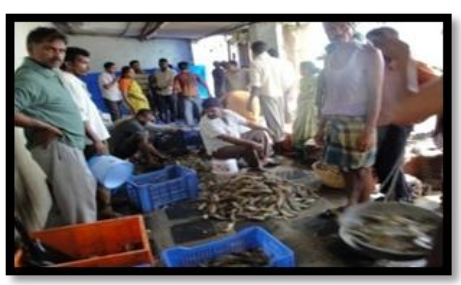

1d Marketing

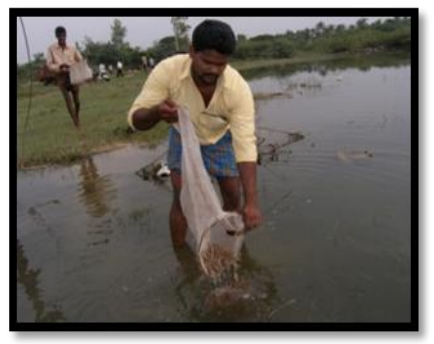

$1 b$ Stocking of seed

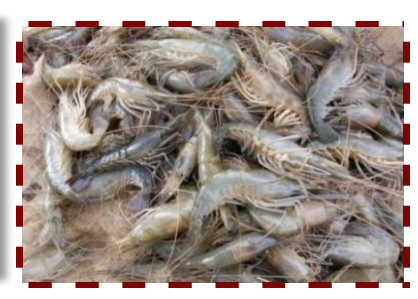

1e Catch of M.malcolmsonii

Fig. 2 Catch composition of freshwater prawn

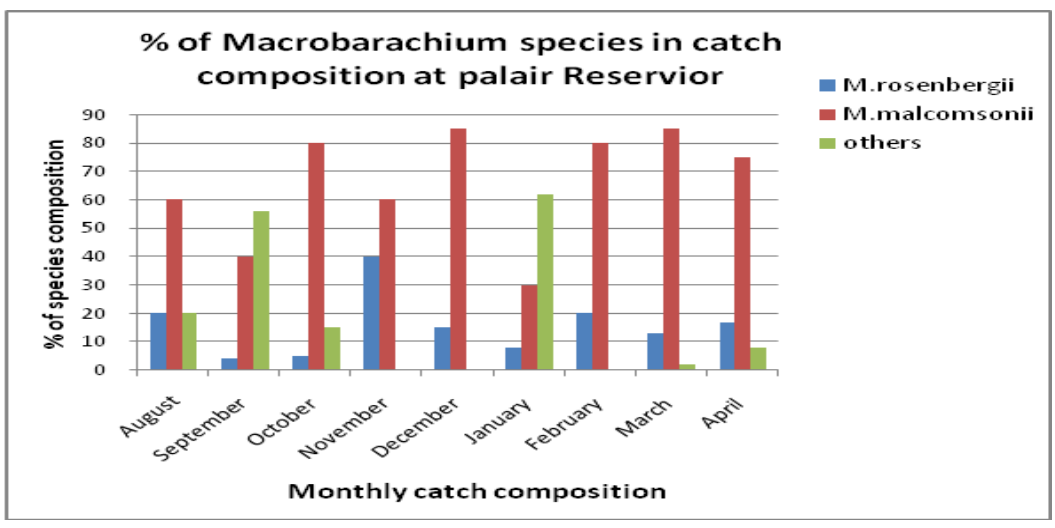


Fig.3 Morphotypes of M.malcolmsonii

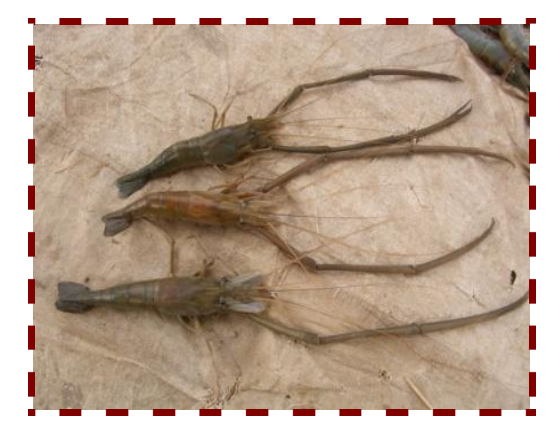

Fig.4 M.rosenbergii

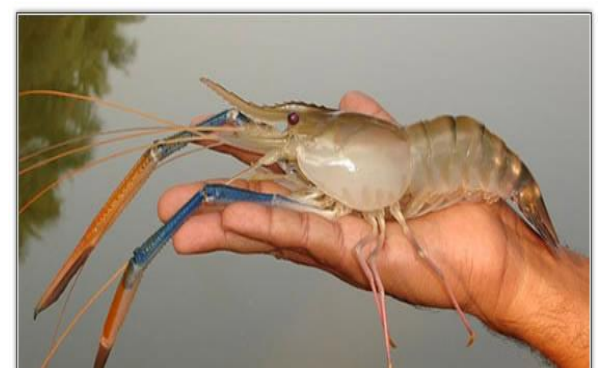

Fig.5 Morphotypes of M.rosenbergii

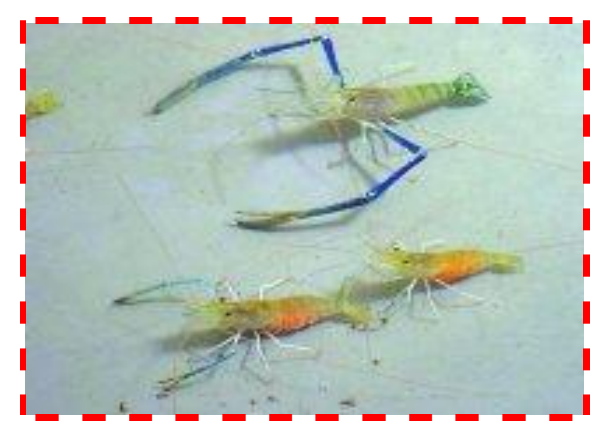

Fig.6 Growth performance of freshwater prawn

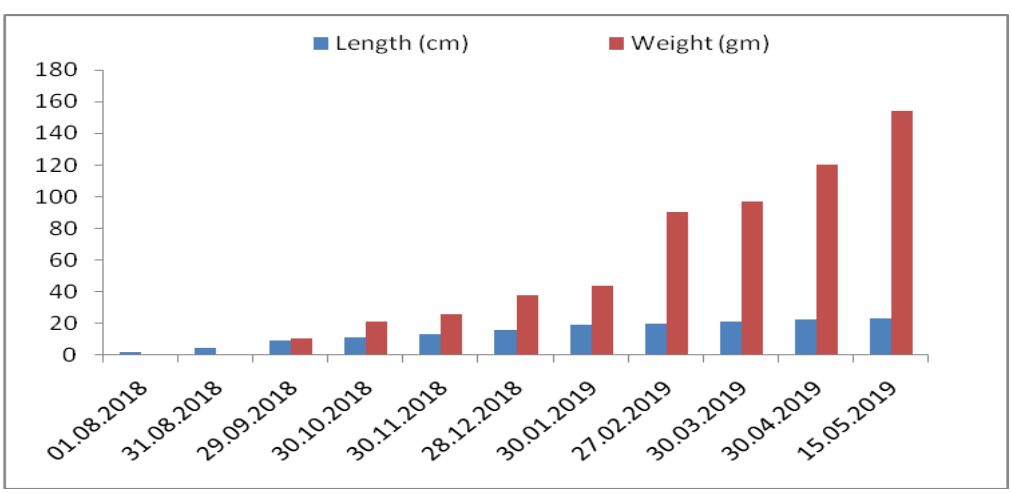


Fig. 7 Seasonal variance of plankton

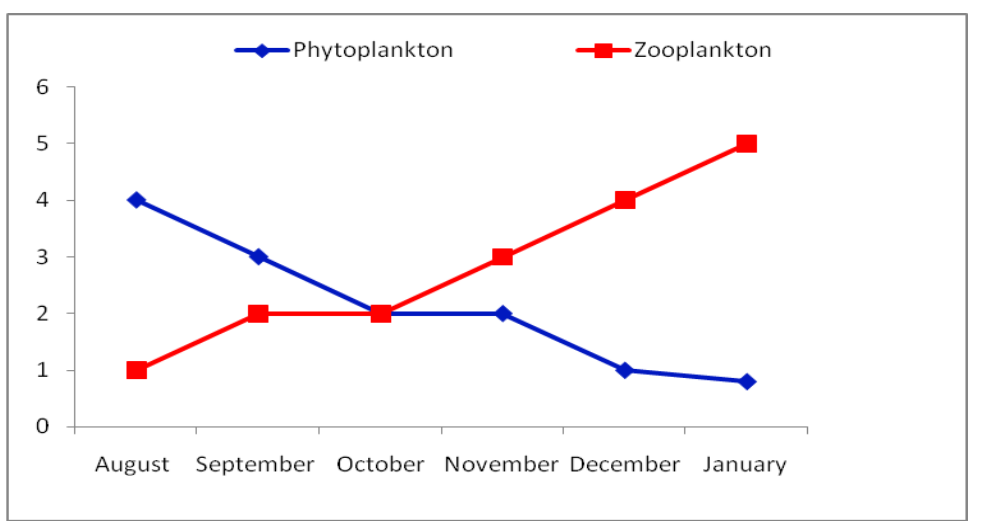

Fig. 8 Production potentiality of Freshwater prawn in Palair Reservoir

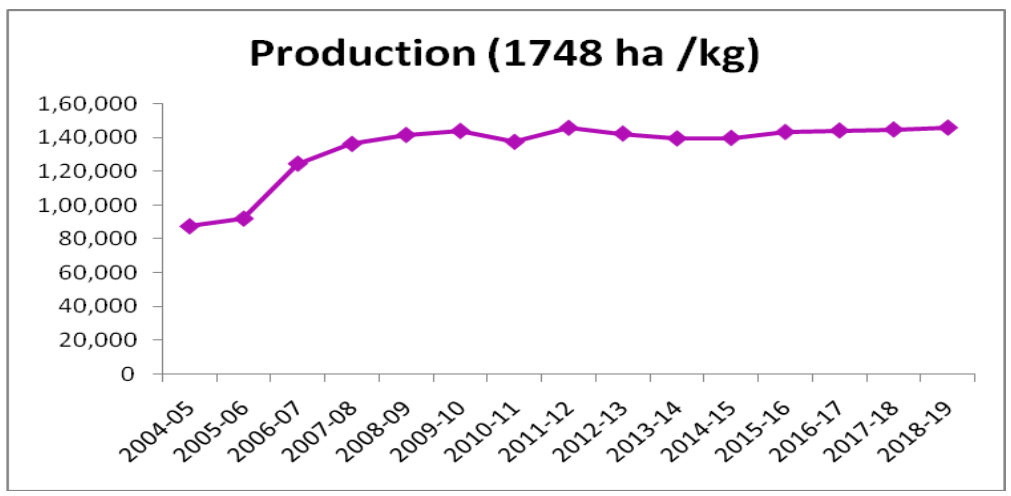

The physical, chemical and hydro-biological water quality parameters of Palair reservoir are very optimum for the survival and growth of aquatic animals (fish and prawn). Qualitatively and quantitatively it is rich in plankton production. The ichthyo fauna harbour on an average 60 species of fishes, of which at least 40 contribute to the commercial fisheries (Roy, M.K.D. et al., 2015 and Valarmathi, K. 2017). Though the Indian major carps occupy a prominent place among the commercial important species, more recently exotic species, murrels and freshwater prawns sps. also contribute substantiously to commercial species.

The total fish and prawn production from Palair reservoir is 60 metric / annum (2004$05)$ and the production of prawn touches 130 -145 tonnes as against the 70 tonnes of fish
(2018-19). The returns from prawn accounted for two thirds of the total income from the reservoir. The aquaculture production of this reservoir is representing the whole Telangana aqua production.

In conclusion the global market for scampi is expanding with attractive prices and thus there is scope for an expansion of scampi production and export. About 4-5 million ha of impounded freshwater bodies in the various states of India, offer the potential for freshwater prawn culture. Although aqua production of giant freshwater prawn, Macrobrachium rosenbergii in India has shown a phenomenal increase in recent years, the major bottle neck for the further expansion of prawn culture is the lack of adequate supply of prawn post larvae for stocking. 
Still there are vast opportunities to increase productivity from the reservoirs. Timely and quality fish and prawn seed stocking is required to augment production levels. Moreover a sound marketing system will also fetch higher incomes which will further improve the socio-economic status of fishermen community.

Palair Reservoir is an additional source of income aside from the regular reservoir fishery in the state. The cooperative fishermen society of this area is the largest of all with 1500 society members.

This reservoir is livelihood for eight villages (Thanda) around. To meet the demand, production from this reservoir is till wanting. By application of scientific management tools the production and productivity levels can be still enhanced and the socio-economic standards of the cooperative societies of the fishermen community can be upgraded.

\section{References}

Laxmappa, B. and Vijay Babu, B., 2014. Opportunities in Mahabubnagar district Andhra Pradesh for improving the livelihood of Fishers through Reservoir Fisheries, Fishing Chimes, 33 (12): 2628.

Laxmappa. B., Satya Parameswar, K. and Srinivas Reddy, B. 2013. Status of Freshwater prawn farming in Ramanpad reservoir in Mahabubnagar district of Andhra Pradesh., Fishing Chimes, 33(7): 29-31.

Roy, M.K.D., S. Rath and S. Mitra, 2015. Faunistic and Limnological studies on Palair lake, Wetland Ecosystem series 18. Published by zoological survey of India, 63-68 pp.

Valarmathi, K. 2017 Crustacea: Decapoda (Prawns and crabs), pp-313-331. In: Current status of freshwater faunal diversity in India. Published by zoological survey of India.

\section{How to cite this article:}

Suguna, T. 2020. Production Potentiality of Freshwater Prawn in Palair Reservoir. Int.J.Curr.Microbiol.App.Sci. 9(10): 3216-3222. doi: https://doi.org/10.20546/ijcmas.2020.910.384 